\title{
АНАЛІЗ ЗАХВОРЮВАНОСТІ НА ВАКЦИНОКЕРОВАНІ ІНФЕКЦІ У РІЗНИХ КРА НАХ СВІTУ
}

\author{
(ㄱ. О. Федяк, І. П. Білик, І. І. Іванюлик \\ Івано-Франківський національний медичний університет
}

\begin{abstract}
РЕЗЮМЕ. У статті представлені результати опрацювання динаміки поширеності та показників стану вакцинокерованих інфекційних хвороб (кашлюку, менінгококово інфекці, кору, краснухи) за даними Звітів Європейського Центру профілактики і контролю захворювань та Департаменту охорони здоров'я штату Каліфорнія (США). Встановлений ріст поширеності цих хвороб у кра нах ЄС і США, що пов'язано, у першу чергу, із огріхами у проведенні вакцинаці та наявністю нестійкого імунного прошарку серед сучасно людсько популяці .

КЛЮЧОВІ СЛОВА. Поширеність вакцинокерованих інфекційних хвороб, кашлюк, менінгококова інфекція; кір; краснуха.
\end{abstract}

Вступ. Інфекційні хвороби все ж залишаються небезпечними для людства, займають провідне місце у структурі захворюваності населення, призводять до тимчасово втрати працездатності, інвалідності та смертності населення в усіх кра нах світу. Найефективнішим і найдієвішим заходом комплексного підходу боротьби з низкою інфекційних хвороб, стримуючим фактором спалахів епідемій $\epsilon$ імунопрофілактика, що, за визначенням ВООЗ, $\epsilon$ «питанням національно безпеки» [3]. В системі охорони здоров'я ЄС функціонує агентство - Європейський центр з запобігання і контролю за захворюваннями (ECDC), в завдання якого входять виявлення, оцінка, повідомлення про поточні та загрозливі для здоров'я людини інфекційні хвороби.

Метою дослідження став аналіз щорічних Звітів спостереження за епідеміологічною ситуацією керованих інфекцій за 2008-2012 рp. ECDC та Департаменту охорони здоров'я штату Каліфорнія.

Матеріал і методи дослідження: бібліограФічний, системно-логічний.

Результати й обговорення. Кашлюк - висококонтагіозне бактеріальне захворювання, спричинене B. Pertusis, з проявами нападоподібного кашлю, який часто завершується виділенням густого прозорого слизу чи блюванням. Захворюваність на кашлюк має циклічний характер і його піки бувають через кожні 3-5 рр. [2]. За даними Звіту спостереження за епідеміологічною ситуацією керованих інфекцій за 2014 р. ECDC у 20082012 рр. було зареєстровано 42525 випадків кашлюку (серед них - 38840 підтверджених). Представлені дані стосувалися 28 кра н Європейського Союзу (ЄC) та кра н Європейсько Економічно Зони (ЄЕЗ), 26 з яких мають національну систему епідеміологічного нагляду. Показники зареєстрованих і підтверджених випадків кашлюку в ЄC/ ЄЕЗ за період 2008 - 2012 рр. представлено у таблиці 1 [3].

Як свідчать результати досліджень ECDC, подані у таблиці 1, загальні відносні показники захворюваності на кашлюк у 2012 р. становили 10,93 на 100000 населення, що вдвічі більше, ніж в попередні роки. Найвищий показник захворюваності спостерігався у Норвегі 85,18 випадків на 100000 населення. Нідерланди, Данія, Великобританія і Словаччина показали 76,$91 ; 20,36 ; 19,04$ і 16,97 випадків на 100000 відповідно. У Нідерландах зареєстровано найбільшу кількість випадків ( $\mathrm{N}=12868)$, це вдвічі більше, ніж у 2011 р., що склало 30 \% від загально кількості випадків ЄС/ЄЕЗ. У Великобритані також у 2012 р. спостерігалось майже в десять раз більше випадків, ніж у 2011 р. (1 256 випадків у 2011 році проти 11993 випадків у 2012 р.), що складає 28 \% від загального числа випадків, зареєстрованих в кра нах ЄС/€ЕЗ.

Найвразливішою віковою групою були діти 514 рр. Найбільше дітей, які захворіли на кашлюк, були з кран, які повідомили про високу загальну захворюваність (Норвегія і Нідерланди). Для інших кра н найбільш постраждалою групою були діти у віці до 5 р. Віковий та гендерний розподіл захворюваності на кашлюк в кра нах ЄС/ЄЕЗ за 2012 р. зображено на рисунку 1.

За даними Департаменту охорони здоров'я штату Каліфорнія (CDPH), у 2014 р. спостерігалась епідемія кашлюку в Каліфорні. Цей штат за площею та населенням наближений до Украни. Показники захворюваності на кашлюк у штаті Каліфорнія (США) подані у таблиці 2.

Отже, на початок 2014 р. зареєстровано 9935 випадків кашлюку. За даними CDPH, 347 осіб у 2014 р. госпіталізовано, 80 (23 \%) з них потребували інтенсивно терапі. Більшість випадків зареєстровано у немовлят та дітей до 18 р. (7,539; $89 \%)$, пік захворюваності припадає на вік 1 р. і 15 р.: 611 (8 \%) педіатричних випадків були серед грудних дітей віком до 6 місяців, 4867 осіб (65\%) були діти / підлітки 7-16 рр., з 6420 (85 \%) дітей 658 (10\%) ніколи не були вакциновані від кашлюку (рис. 2) [2]. 
Оеляди літератури, ориаінальні дослідження, поеляд на проблему

Таблиця 1. Динаміка показників захворюваності на керовані бактерійні інфекці у кра нах ЄC/ЄE3 (на 100000 населення)

\begin{tabular}{|c|c|c|c|c|c|c|c|c|c|c|}
\hline \multirow{2}{*}{ Країна } & \multicolumn{5}{|c|}{ Кашлюк } & \multicolumn{5}{|c|}{ Менінгококова інфекція } \\
\hline & 2012 & 2011 & 2010 & 2009 & 2008 & 2012 & 2011 & 2010 & 2009 & 2008 \\
\hline Австрія & 5,06 & 1,30 & 2,82 & 0,02 & 2,10 & 0,67 & 0,60 & 1,02 & 1,07 & 1,01 \\
\hline Болгарія & 1,24 & 0,48 & 0,30 & 1,78 & 1,73 & 0,11 & 0,18 & 0,11 & 0,21 & 0,27 \\
\hline Кіпр & 1,39 & 0,12 & 0,00 & 0,63 & 0,39 & - & - & 0,12 & 0,13 & 0,26 \\
\hline Чехія & 6,73 & 2,96 & 6,27 & 9,14 & 7,38 & 0,56 & 0,60 & 0,57 & 0,77 & 0,79 \\
\hline Данія & 20,36 & 7,97 & 8,13 & 11,47 & 11,30 & 1,00 & 1,30 & 1,19 & 1,29 & 1,17 \\
\hline Естонія & 11,17 & 35,42 & 95,93 & 46,96 & 36,16 & 0,45 & 0,53 & 0,15 & 0,37 & 0,45 \\
\hline Фінляндія & 10,02 & 10,33 & 6,41 & 5,01 & 19,28 & 0,61 & 0,63 & 0,64 & 0,62 & 0,53 \\
\hline Франція & \multicolumn{5}{|c|}{ дані відсутні } & 0,84 & 0,87 & 0,79 & 0,94 & 1,03 \\
\hline Німеччина & \multicolumn{5}{|c|}{ дані відсутні } & 0,43 & 0,45 & 0,47 & 0,60 & 0,55 \\
\hline Греція & 0,36 & 0,02 & 0,49 & 0,14 & 0,09 & 0,53 & 0,47 & 0,49 & 0,69 & 0,70 \\
\hline Угорщина & 0,05 & 0,09 & 0,25 & 0,31 & 0,33 & 0,52 & 0,68 & 0,38 & 0,38 & 0,30 \\
\hline Ірландія & 5,76 & 2,47 & 0,99 & 1,37 & 1,59 & 1,31 & 1,95 & 2,15 & 2,96 & 3,41 \\
\hline Італія & 0,44 & 0,85 & 0,78 & 1,06 & 0,57 & 0,23 & 0,26 & 0,25 & 0,31 & 0,31 \\
\hline Латвія & 9,10 & 0,10 & 0,28 & 0,05 & 0,32 & 0,20 & 0,10 & 0,24 & 0,19 & 0,32 \\
\hline Литва & 4,62 & 0,79 & 0,51 & 7,32 & 1,59 & 1,77 & 1,38 & 1,53 & 1,23 & 1,49 \\
\hline Люксембург & 2,00 & 0,78 & 0,00 & 0,20 & 0,41 & 0,57 & 0,39 & 0,20 & 0,61 & 0,41 \\
\hline Мальта & 0,52 & 4,82 & 0,48 & 0,00 & 0,00 & 0,96 & 1,45 & 0,48 & 1,22 & 0,74 \\
\hline Нідерланди & 76,24 & 32,69 & 22,52 & 34,89 & 52,16 & 0,65 & 0,64 & 0,86 & 0,92 & 0,99 \\
\hline Польща & 0,00 & 1,76 & 1,50 & 2,77 & 3,34 & 0,62 & 0,73 & 0,60 & 0,79 & 0,89 \\
\hline Португалія & 2,43 & 0,31 & 0,13 & 0,61 & 0,66 & 0,66 & 0,74 & 0,77 & 0,63 & 0,59 \\
\hline Румунія & 0,36 & 0,38 & 0,15 & 0,05 & 0,23 & 0,35 & 0,34 & 0,26 & 0,51 & 0,51 \\
\hline Словаччина & 16,64 & 17,36 & 25,53 & 5,35 & 1,84 & 0,57 & 0,39 & 0,69 & 0,73 & 0,89 \\
\hline Словенія & 8,51 & 8,59 & 18,12 & 17,27 & 8,06 & 0,44 & 0,63 & 0,44 & 0,74 & 1,19 \\
\hline Іспанія & 3,15 & 2,17 & 0,66 & 0,27 & 0,44 & 0,72 & 0,93 & 0,87 & 1,15 & 1,29 \\
\hline Швеція & 2,87 & 1,83 & 2,82 & 3,01 & 5,00 & 1,09 & 0,72 & 0,72 & 0,70 & 0,53 \\
\hline В. Британія & 18,89 & 2,01 & 0,59 & 1,38 & 1,72 & 1,36 & 1,66 & 1,62 & 1,94 & 2,22 \\
\hline СС загалом & 10,64 & 3,61 & 3,11 & 3,63 & 4,61 & 0,68 & 0,76 & 0,73 & $\mathbf{0 , 8 9}$ & 0,96 \\
\hline Ісландія & 9,43 & 0,00 & 0,00 & 0,00 & 0,32 & - & 0,63 & 0,63 & 1,57 & 0,63 \\
\hline Норвегія & 82,98 & 88,78 & 73,28 & 115,5 & 82,05 & 0,48 & 0,75 & 0,80 & 0,92 & 0,76 \\
\hline СС/СЕЗ загалом & 11,87 & 4,83 & 4,10 & 5,18 & 5,67 & 0,68 & 0,76 & 0,74 & $\mathbf{0 , 8 9}$ & 0,95 \\
\hline
\end{tabular}

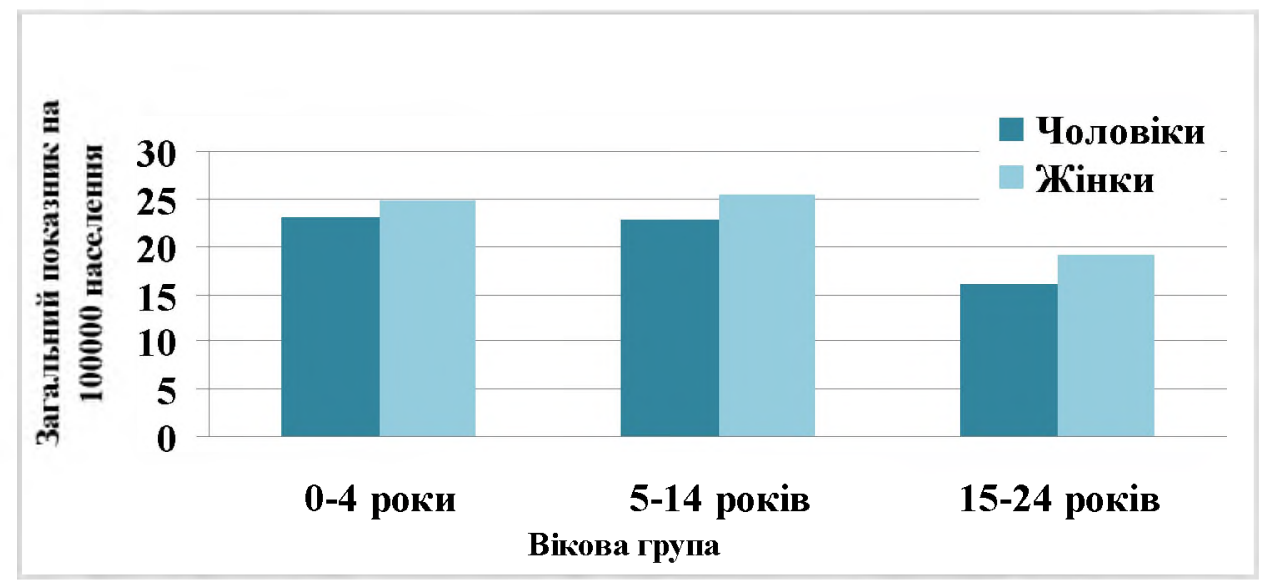

Рис. 1. Гендерний та віковий розподіл захворюваності на кашлюк в кра нах ЄС/ЄЕЗ на 100 тис. населення за 2012 p.

Таблиця 2. Динаміка захворюваності на кашлюк в Каліфорні (на 100 тисяч населення)

\begin{tabular}{|c|c|c|c|c|c|c|c|c|c|}
\hline \multicolumn{2}{|c|}{2010 p. } & \multicolumn{2}{c|}{$2011 \mathrm{p}}$. & \multicolumn{2}{c|}{$2012 \mathrm{p}}$. & \multicolumn{2}{c|}{$2013 \mathrm{p}}$. & \multicolumn{2}{c|}{$2014 \mathrm{p}}$. \\
\hline абс. & відн. & абс. & відн. & абс. & відн. & абс. & відн. & абс. & відн. \\
\hline 9159 & 24,54 & 3016 & 8,03 & 1023 & 2,70 & 2537 & 6,64 & 9935 & 26,00 \\
\hline
\end{tabular}


Оеляди літератури, оригінальні дослідження, поеляд на проблему

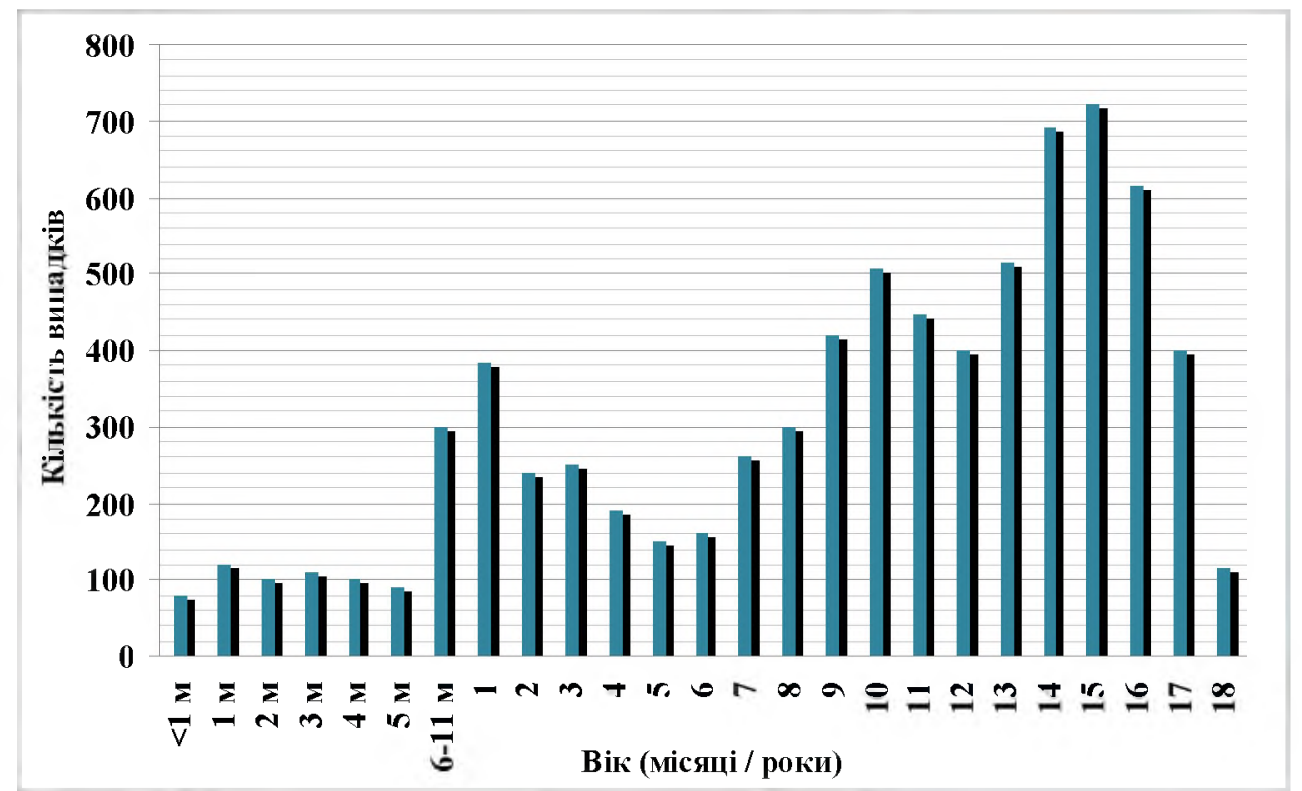

Рис. 2. Дитячі випадки захворювання на кашлюк у Каліфорні , 2014 р.

Менінгококова інфекція (MI) - антропонозна гостра хвороба з групи інфекцій дихальних шляхів, що зумовлюється менінгококом Neisseria meningitidis i характеризується клінічним поліморфізмом у вигляді назофарингіту, гнійного менінгіту і сепсису. Neisseria meningitidis оточена полісахаридною капсулою і має 12 серогруп.

Захворювання спричиняють переважно серогрупи A, B, C, W135 та Ү. У світі відзначено варіабельність щодо поширеності серогруп залежно від часу та географі. Так, у США найпоширенішими $\epsilon$ серогрупи В, С, Ү. На сьогодні у кра нах Європи домінують серогрупи В та С, у той же час захворювання на МІ у кра нах Азі та Африки асоціюються із серогрупами A та W135 [1, 4].

За результатами Звіту спостереження за епідеміологічною ситуацією керованих бактерійних інфекцій ECDC у 2012 р. про 3467 підтверджених випадків MI повідомили 28 кра н ЄC/ЄЕЗ. Загалом показники захворюваності на МІ в цих кра нах зни- зились з 0,95 випадків на 100000 населення у 2008 р. до 0,68 випадків на 100000 у 2012 р. У Литві, Великобритані та Ірланді зареєстровано найвищі показники захворюваності на МІ (табл. 3).

Найчастіше MI спостерігалася у дітей віком до 5 р. (5,10 на 100000 , обох статей), потім ідуть особи у віці 15-24 pp. (1,11 на 100 000, обох статей). Аналогічні показники при розподілі за статтю, з невеликим переважанням чоловіків в більшості вікових груп (рис. 3) [4].

За даними щорічного Звіту нагляду за вакцинокерованими захворюваннями штату Каліфорнія за 2012 р. було зареєстровано 88 випадків $\mathrm{Ml}(0,23$ на 100000 населення). 75 з них (85\%) спричинені серогрупами В (29; 39 \%) і C (22; 29\%) (рис. 5). Зареєстровано 20 летальних випадків, 40 \% з них спричинені серогрупою С. Спостерігалося 25 випадків MI серед немовлят та дітей молодших 18 років, 3 з яких виявилися летальні. Найвищі показники МI було зафіксовано серед дітей до 1 року (рис. 6) [4].

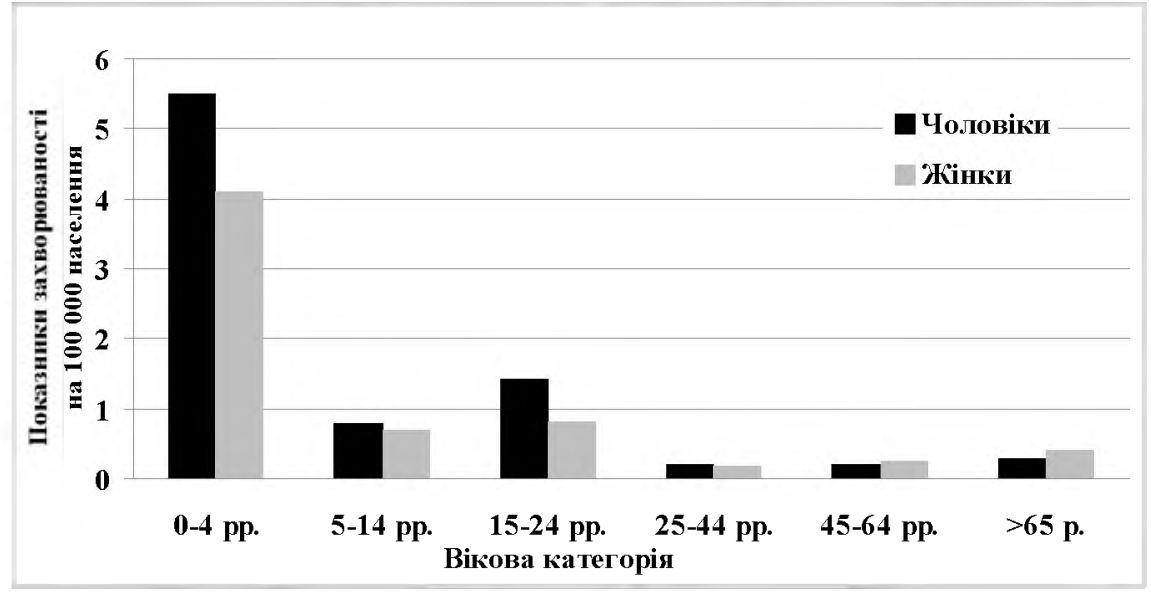

Рис. 3. Віковий та гендерний розподіл хворих на Ml в кра нах ЄC/ЄЕЗ, 2012 p. 
Оеляди літератури, ориеінальні дослідження, поеляд на проблему

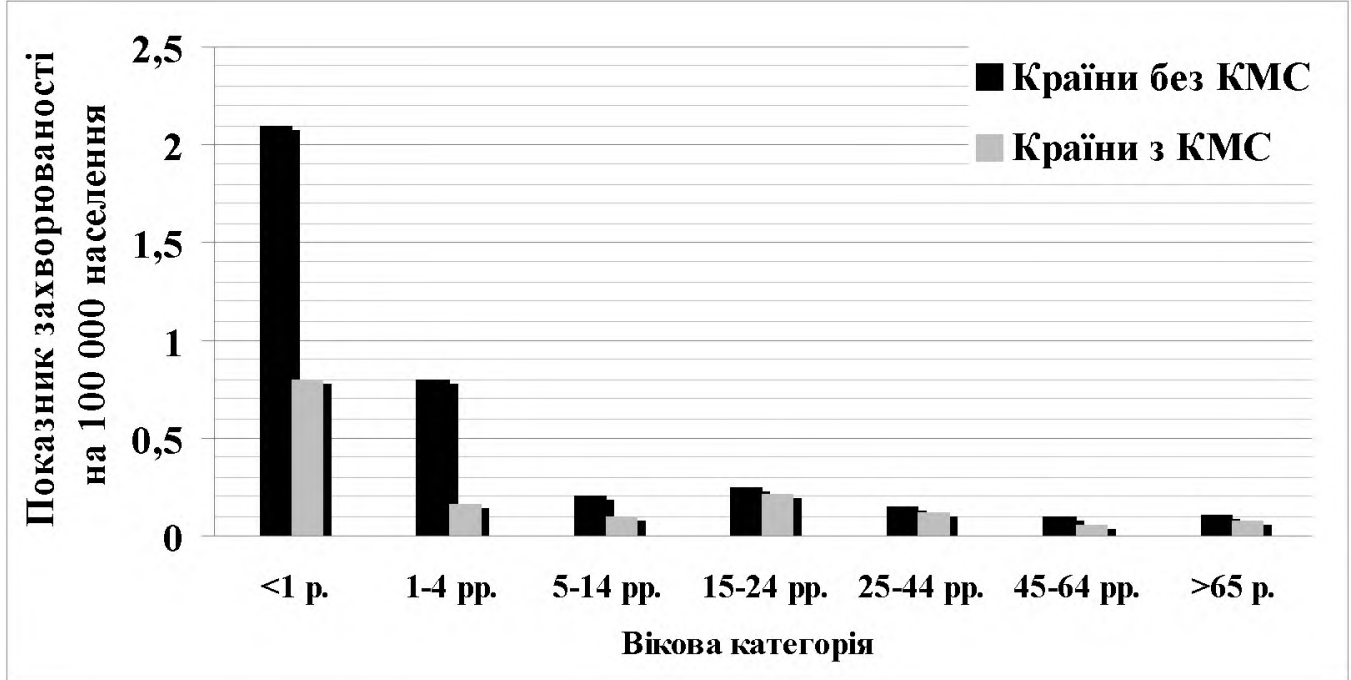

Pис. 4. Показники захворюваності на Ml серогрупи С за віковими групами та наявністю кон'юговано вакцини проти менінгокока С (KMC) в Календарі щеплень, ЄC/ЄE3, 2012 р. ( $N=536)$.

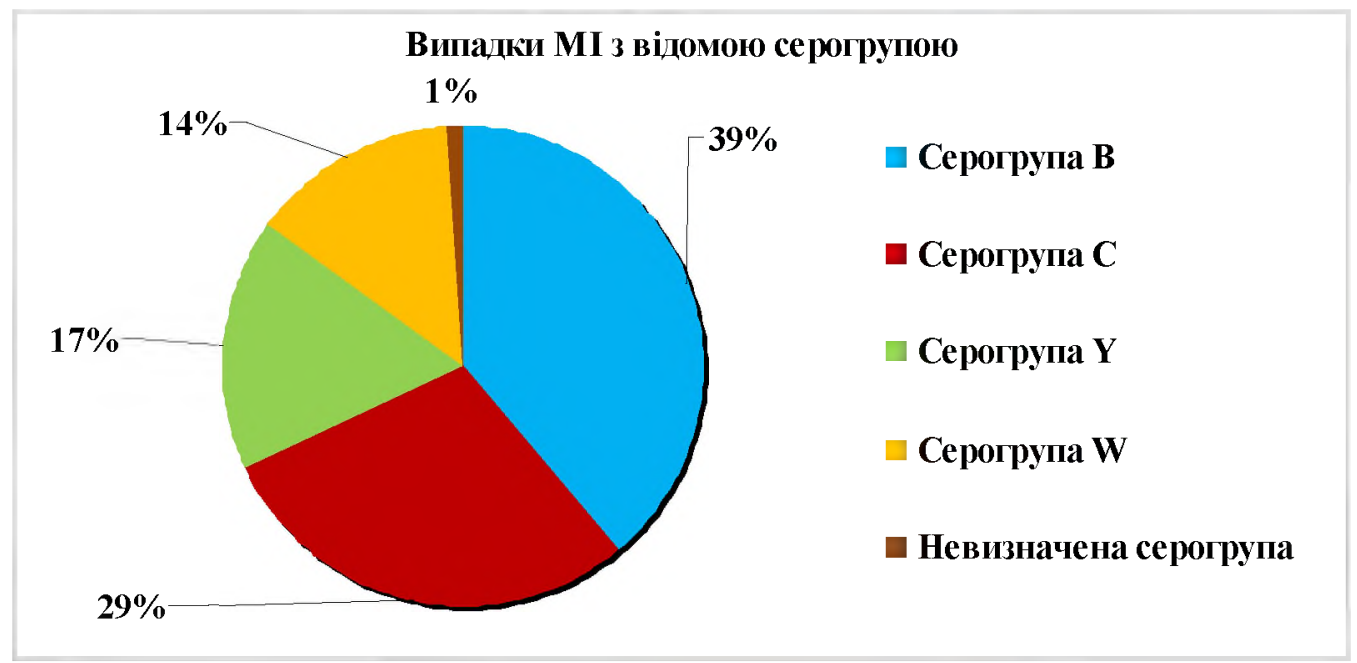

Рис. 5. Розподіл випадків Ml за серогрупами, Каліфорнія, 2012 р. (N = 75).

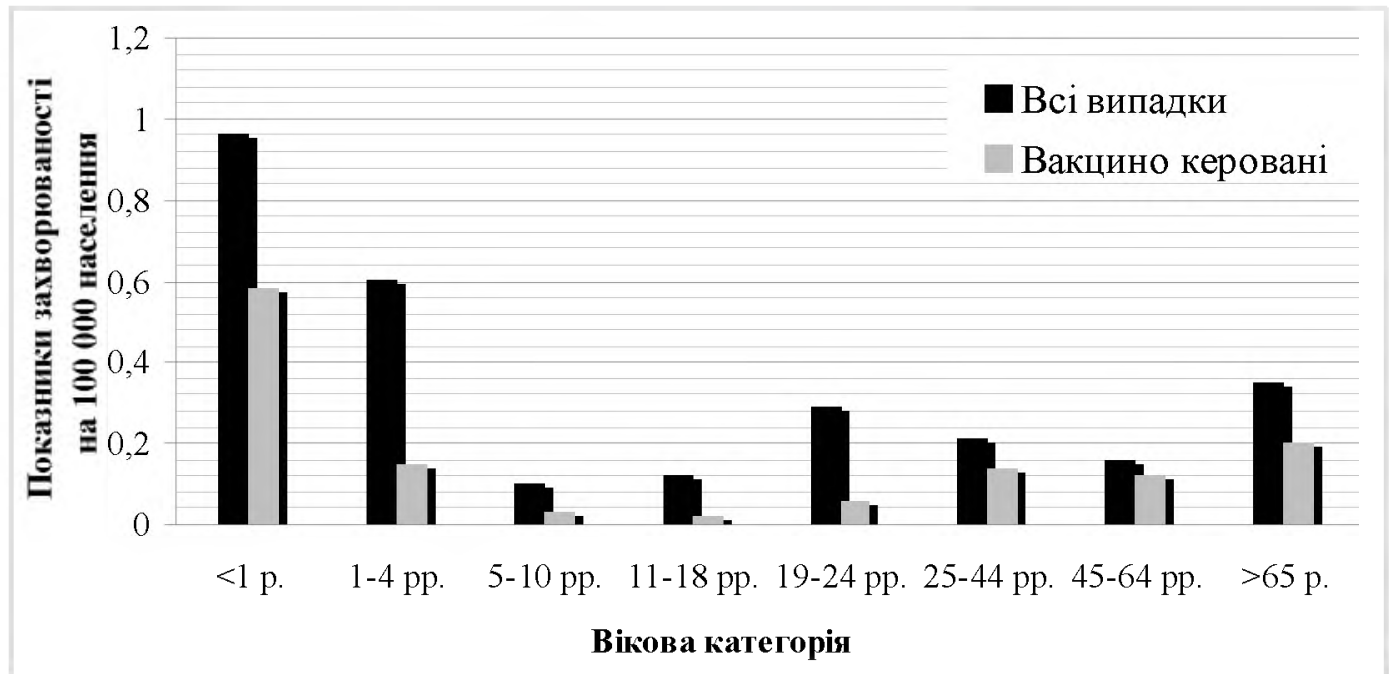

Рис. 6. Показники захворюваності на Мl за віковими групами та проведенням вакцинаці, Каліфорнія, 2012 р. $(\mathrm{N}=88)$. 
Оеляди літератури, оригінальні дослідження, поеляд на проблему

Таблиця 3. Динаміка показників захворюваності на кір та краснуху у кра нах ЄC/ЄE3 (на 100000 населення)

\begin{tabular}{|c|c|c|c|c|c|c|c|c|c|c|}
\hline \multirow{2}{*}{ Країна } & \multicolumn{5}{|c|}{ Kip } & \multicolumn{5}{|c|}{ Краснуха } \\
\hline & 2012 & 2011 & 2010 & 2009 & 2008 & 2012 & 2011 & 2010 & 2009 & 2008 \\
\hline Австрія & 0,42 & 1,45 & 0,67 & 0,63 & 5,37 & 0,2 & 0,3 & 0,18 & 3,7 & 0,14 \\
\hline Бельгія & 0,91 & 6,13 & - & - & - & 4,19 & - & - & - & 0,02 \\
\hline Болгарія & 0,01 & 2,13 & 296,49 & 30,12 & 0,01 & 0,15 & 0,27 & 0,35 & 0,58 & 0,76 \\
\hline Кіпр & 0,12 & 0 & 2,2 & 0 & 0,13 & 0,35 & 0 & 0,24 & 0 & 0 \\
\hline Чехія & 0,21 & 0,16 & 0 & 0,05 & 0,02 & 13,38 & 9,93 & 9,49 & 0,08 & 0,14 \\
\hline Данія & 0,04 & 1,51 & 0,09 & 0,15 & 0,22 & 0,27 & 0,23 & 0,58 & - & - \\
\hline Естонія & 0,3 & 0,53 & 0 & 0 & 0 & 0,08 & 0,15 & 0 & 0,08 & 0,3 \\
\hline Фінляндія & 0,07 & 0,5 & 0,09 & 0,04 & 0,09 & 0,06 & 0,04 & 0,08 & 0 & 0 \\
\hline Франція & 1,32 & 23,04 & 7,77 & 2,4 & 0,94 & - & - & - & - & - \\
\hline Німеччина & 0,2 & 1,97 & 0,96 & 0,7 & 1,12 & - & - & - & - & - \\
\hline Греція & 0,03 & 0,36 & 1,33 & 0,02 & 0,01 & 0,01 & 0 & 0 & 0,04 & 0 \\
\hline Угорщина & 0,02 & 0,05 & 0 & 0,01 & 0 & 0,04 & 0,05 & 0 & 0 & 0 \\
\hline Ірландія & 2,25 & 5,84 & 9,02 & 4,34 & 1,26 & 0,96 & 1,53 & 2,44 & 0,43 & 0,91 \\
\hline Італія & 1,02 & 8,59 & 5,08 & 1,26 & 8,91 & 0,66 & 1,59 & 1,51 & 0,35 & 10,49 \\
\hline Латвія & 0,15 & 0,05 & 0 & 0 & 0,14 & 1,52 & 0,24 & 0 & 0,31 & 0,4 \\
\hline Литва & 0,07 & 0,23 & 0,06 & 0 & 0,03 & 2,06 & 2,1 & 0 & 0 & 0 \\
\hline Люксембург & 0,38 & 1,17 & 0 & 0 & 0 & 0 & 0 & 0 & 0 & 0 \\
\hline Мальта & 0 & 1,45 & 0 & 0,24 & 0,25 & 0 & 0 & 0,48 & 0 & 0,73 \\
\hline Нідерланди & 0,06 & 0,3 & 0,09 & 0,09 & 0,66 & 2,07 & 3,18 & 2,56 & 0,04 & 0,01 \\
\hline Польща & 0,18 & 0,1 & 0,03 & 0,3 & 0,26 & 0,02 & 0 & 0,01 & 20 & 34,57 \\
\hline Португалія & 0,07 & 0,02 & 0,05 & 0,03 & 0,01 & 0,08 & 0,07 & 0,11 & 0,03 & 0,04 \\
\hline Румунія & 30,68 & 20,09 & 0,94 & 0,04 & 0,07 & 1,01 & 0,03 & 0,3 & 2,8 & 8,18 \\
\hline Словаччина & 0,02 & 0,04 & 0 & 0 & 0 & 0,07 & 0,04 & 0,02 & 0 & 0 \\
\hline Словенія & 0,1 & 1,07 & 0,1 & 0 & 0 & 0,24 & 0,1 & 0,1 & 0 & 0 \\
\hline Іспанія & 2,59 & 7,53 & 0,66 & 0,09 & 0,65 & 5,38 & 1,7 & 0,68 & 0,04 & 0,15 \\
\hline Швеція & 0,32 & 0,28 & 0,06 & 0,03 & 0,27 & 0,3 & 0,32 & 0,17 & 0,01 & 0,17 \\
\hline В. Британія & 3 & 1,73 & 0,64 & 1,89 & 2,3 & 4,29 & 4,34 & 7,06 & 0,01 & 0,06 \\
\hline $\begin{array}{l}\text { СС } \\
\text { загалом }\end{array}$ & 2,26 & 6,41 & 6,65 & 1,38 & 1,92 & 2,95 & 1,84 & 2,12 & 2,09 & 5,04 \\
\hline Ісландія & 0 & 0 & 0 & 0 & 0 & 0 & 0 & 0,63 & 0 & 0 \\
\hline Норвегія & 0,08 & 0,81 & 0,06 & 0,04 & 0,08 & 0,58 & 0,33 & 0,25 & 0 & 0,02 \\
\hline $\begin{array}{l}\text { EС/EE3 } \\
\text { загалом } \\
\end{array}$ & 2,23 & 6,35 & 6,58 & 1,37 & 1,9 & 2,91 & 1,81 & 2,1 & 2,09 & 5,02 \\
\hline
\end{tabular}

Кір - одне з найпоширеніших гострих інфекційних захворювань, яке характеризується підвищенням температури тіла, інтоксикацією, ураженням верхніх дихальних шляхів. Враховуючи небезпечність кору для людини ВООЗ визначила елімінацію кору приорітетною метою в 4 регіонах світу, в тому числі і $Є$ вропейському. Критерієм елімінаці кору вважається рівень захворюваності, не вищий, ніж 1 випадок на 1 мільйон осіб $[1,3]$.

За період календарного 2014 року 30 кран $€ C / € Е 3$, які здійснюють нагляд за кором, повідомили про 3616 випадків захворювання. Цей показник $\varepsilon$ низьким, порівняно з 2010 ( $\mathrm{N}=32480), 2011$

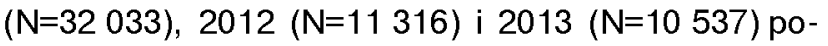
ками. У дев'яти із тридцяти кра н спостерігалося менше 1 випадку кору на 1 мільйон населення (серед них у шести кра нах $\mathrm{N}=0$ ). Найбільше випадків хвороби в аналізований період було зафік- совано в Італі (46,3 \%) і Німеччині (12,3 \%). Із жовтня 2014 року триває спалах кору в Берліні та у Словені , спостерігається підвищена захворюваність на кір у Босні і Герцеговині, Сербі, Киргизстані [3].

За межами Європи спалахи кору зафіксовані в США, Канаді, Кита, Судані та Папуа-Новій Гвіне . Водночас не було повідомлень про випадки смертей, спричинених збудником кору, упродовж 2014 року [1].

Загалом найвищі показники цього захворювання у кра нах $€ C / € Е 3$ були зафіксовані у 2010 році (рис. 7, табл. 3).

Найвища захворюваність на кір у Європейському регіоні у 2014 році була серед дітей віком до одного року (рис. 8).

За даними CDPH, у 2011 р. кількість випадків кору у Каліфорні (США) становила 31, а у 2012 р. 8 випадків (табл. 4). 
Оеляди літератури, оригінальні дослідження, поеляд на проблему

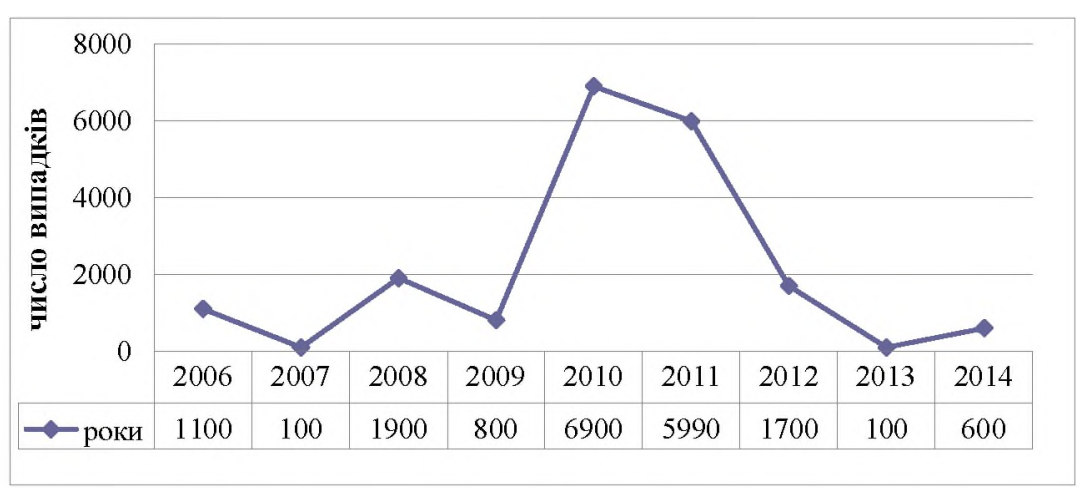

Рис. 7. Число випадків кору в кра нах ЄС/ЄЕЗ з 01.2006 р. по 12.2014 р.

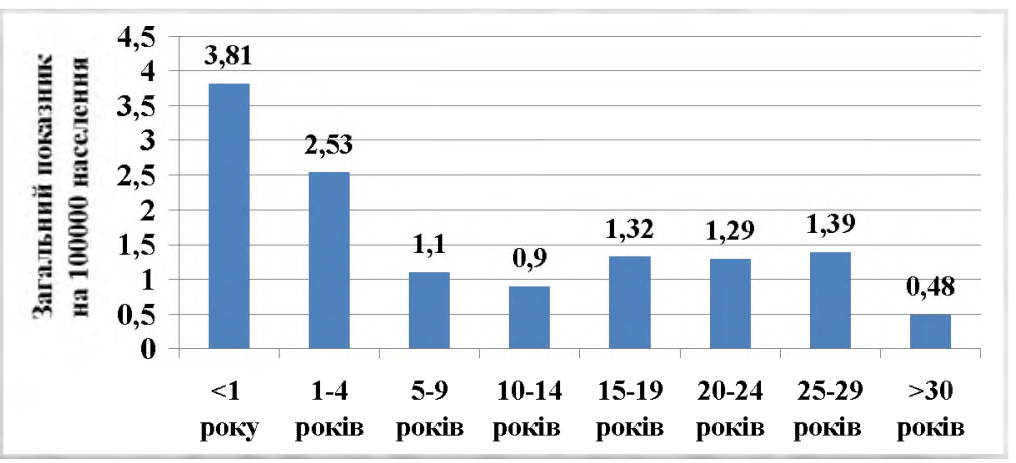

Рис. 8. Показники захворюваності на кір в ЄС/ЄЕЗ за віком станом на грудень 2014 р.

Таблиця 4. Аналіз захворюваності на кір в Каліфорні у 2012 р. (N=8)

\begin{tabular}{|c|c|c|c|}
\hline \multicolumn{2}{|c|}{} & Число випадків & \% \\
\hline \multirow{3}{*}{ Стать } & Чоловіки & 4 & 50 \\
\cline { 2 - 4 } & Жінки & 4 & 50 \\
\hline \multirow{3}{*}{ Biк } & $0-1$ & 0 & 13 \\
\cline { 2 - 4 } & $2-5$ & 1 & 38 \\
\cline { 2 - 4 } & $6-18$ & 3 & 38 \\
\cline { 2 - 4 } & $19-54$ & 1 & 13 \\
\cline { 2 - 4 } & $>55$ & 3 & - \\
\hline
\end{tabular}

Краснуха - вірусна хвороба, яка характеризується дрібним висипом, збільшенням лімфовузлів, помірно вираженою лихоманкою. Захворювання на краснуху на 3-4-му тижні вагітності зумовлює вроджені каліцтва у $60 \%$ випадків, на 9-12-му тижні - у $15 \%$ і на 13-му тижні - у $7 \%$ випадків [1, 3].

За даними ECDC, у кра нах ЄC/ЄE3 у січнігрудні 2014 р. було зареєстровано 6110 випадків краснухи: у 22 з 26 кра н, які оприлюднили повідомлення, захворюваність була менша, ніж 1 випадок на 1 мільйон населення, в т.ч. 13 кран повідомили про нульовий показник. Більшість випадків краснухи у 2014 було у Польщі: найвищий показник захворюваності у цій кра ні спостерігався серед 5-9-річних ( $\mathrm{N}=1710)$ і 1-4-річних $(\mathrm{N}=1213)$. Така ж вікова тенденція мала місце і загалом по ЄC/ЄE3 (рис. 9) [1].

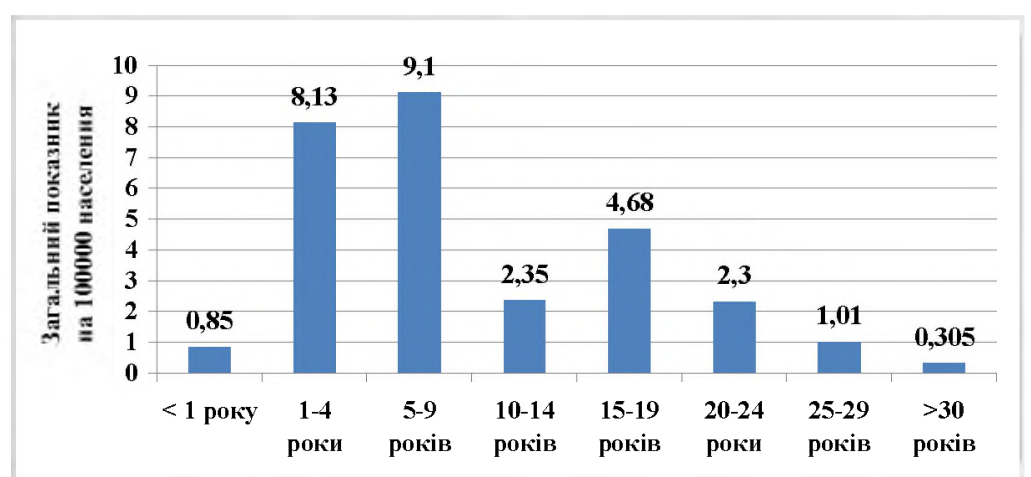

Рис. 9. Показники захворюваності на краснуху в ЄC/ЄЕЗ за віком станом на грудень 2014 р. 
Оеляди літератури, оригінальні дослідження, поеляд на проблему

у 2010-2012 рр. найвищий показник захворюваності на краснуху був зафіксований у Чеській Республіці, у 2008-2009 рр., як і у 2014 р. - у Польщі (табл. 3). У штаті Каліфорнія (США) повідомлялося про 1 випадок краснухи у 2012 р. в емігранта з Японі .

Висновки. Ріст захворюваності на кашлюк, що спостерігається в кра нах Європи та США, потребує покращення контролю вакцинопрофілактики ціє хвороби, а зниження показників захворюваності на MI зумовлене рутинною імунізацією населення. Водночас кількість випадків кору в кра нах $Є C$ у 2014 р. $\epsilon$ значно нижчою, ніж у попередні роки. Це пов'язано з динамікою передачі інфекці в популяці, оскільки епідемі останніх років призвели до скорочення числа сприйнятливих осіб серед населення в різних кра нах. Bce ж число випадків залишається високим, а кір і краснуха планують ліквідувати в Європі до 2015 року. Аналіз показників захворюваності на ці хвороби в останні роки свідчить про необхідність подальшого відтермінування строків елімінаці.

Перспективи подальших досліджень. Оскільки дане дослідження стосувалося вивчення динаміки поширеності дитячих керованих інфекцій у кра нах ЄС та штаті Каліфорнія (США), доцільним $\epsilon$ опрацювання показників захворюваності на ці хвороби за даними Державно санітарно-епідеміологічно служби Укра ни, що і стане метою нашо подальшо роботи.

\title{
ЛІТЕРАТУРА
}

1. California Department of Public Health. Annual report. Vaccine-Preventable Disease Surveillance in California, 2012. - Режим доступу: http://www.cdph.ca.gov/programs/ immunize/Pages/VaccinePreventableDiseaseSurveillance.aspx - Назва з екрану.

2. California Department of Public Health. Pertussis Summary Reports - Режим доступу:http://www.cdph.ca.gov/ programs/immunize/pages/pertussissummaryreports.aspxНазва з екрану.

3. European Centre for Disease Prevention and Control. Annual epidemiological report 2014 -vaccine-preventable

diseases. Stockholm: ECDC; 2014. - Режим доступу: http:/ /www.ecdc.europa.eu/en/publications/surveillance_reports/ Pages/index.aspx - Назва з екрану.

4. European Centre for Disease Prevention and Control. Annual Epidemiological Report - vaccine-preventable diseases-invasive bacterial diseases. Stockholm, February 2015. - Режим доступу: http://www.ecdc.europa.eu/en/ publications/_layouts/forms/Publication_DispForm.aspx? List=4f55ad51-4aed-4d32- b960-af70113dbb90\&ID=1256Назва з екрану.

\section{ANALYSIS OF THE INCIDENCE OF VACCINE CONTROLLED INFECTION IN DIFFERENT COUNTRIES}

\author{
○I. O. Fedyak, I. P. Bilyk, I. I. Ivanuylyk \\ Ivano-Frankivsk National Medical University
}

SUMMARY. The article presents the results of a study of the dynamics of prevalence and indicators of the state of vaccine controllable infectious diseases (whooping cough, meningococcal disease, measles, rubella) according to a Report from the European Centre for disease prevention and control of diseases and health Department of the state of California (USA). Installed the increased prevalence of these diseases in the EU and USA, due, primarily, to programe in vaccination and the presence of unstable immune layer among modern human populations.

KEY WORDS: Prevalence of vaccine controllable infectious diseases, whooping cough, meningococcal disease, measles, rubella. 